\title{
LINGUISTIC ASPECTS AS CREATIVITY EXPRESSION IN COMPUTER-MEDIATED BUSINESS COMMUNICATION
}

\author{
Irena DARGINAVIČIENĖ (D *, Jelena SUCHANOVA (D) \\ Vilnius Gediminas Technical University, Faculty of Creative Studies, Language Studies Centre, \\ Division of Foreign Languages, Sauletekio al. 11, LT-10223 Vilnius, Lithuania
}

Received 16 December 2019; accepted 6 May 2020

\begin{abstract}
Business communication online has developed over time due to the constant change of modern communication technologies. Researchers affirm that digital technologies have both positive and negative impact on business communication. Creativity in business communication turns to be crucial in the realization of business opportunities. However, it is linked not only to imagination or original ideas. It also means innovation and innovativeness, the use of innovative digital technologies that help to fuel great ideas, enhance critical thinking, open new ways to business ambitions. The study is devoted to the analysis of linguistic aspects in computer-mediated business communication. Two types of digital business discourse - e-mail and websites of insurance companies - are analyzed with the focus on their linguistic features. From the linguistic point of view computer-mediated business communication differs from conventional business communication and the use of lexicon (e.g. special formal and standard vocabulary) is critical in making this communication successful. Grammatical features of business language are also of great relevance. Stylistic features employed in business communication are also crucial since they help to provide emphasis, achieve clarity and freshness of expression. Linguistic elements of computer-mediated communication in e-mails and analysed websites do not always coincide. The analysis has shown that websites tend to be less formal and compared to e-mails are more exposed to creative linguistic expressions.
\end{abstract}

Keywords: business discourse, computer-mediated communication, creativity, e-mail, linguistic elements, websites of insurance companies.

\section{Introduction}

"Your ability to communicate is the most important skill you can develop to get on the fast track in your career". Brian Tracy

Modern digital technologies have undoubtedly changed the way we live. Due to this influx our lives have become both easier and at the same time more difficult but surely more efficient. Modern technologies - computer and Internet - have added to the extension of

${ }^{\star}$ Corresponding author. E-mail: irena.darginaviciene@vgtu.lt 
the communication space between people and businesses anywhere and anytime. However, this communication space often covers people who speak different languages and who live in different countries with very diverse communication and culture backgrounds. The lack of language proficiency and culture knowledge may often lead to the misinterpretation of the content or the misunderstanding between the communicating parties. In its own turn business communication may then become less effective and successful.

Communication as a research object has been studied by quite a few researchers who tried to look into a variety of communication aspects, their impact on society as a whole and individuals as its members. For instance, Rosengren considered communication as a process which increases our shared knowledge and common sense (2006). Pearson and Nelson examine communication as the process of understanding and sharing meaning (2000). As McLuhan notices, communication means change (2008). For Cherry it is "a prominent predictor of particularly productive creatives" (2019). As stated by Tharp and Reiter, creativity is not just for artists, it is for businesspeople looking for new ways of doing business as well (2009). Yet, communication is not only the tool for sharing information and increasing knowledge. It is also inevitable in business environment as no business can grow and expand without proper communication means and channels. Most studies underline that digital technologies play a positive role in business communication. However, there are authors who state that new communication technologies in business have also negative aspects since they often urge information distortion. Conrad, for instance, assumes that

"we now use technology such as email, text-messaging, social media, and video teleconferencing communication, which has made it easier to communicate, but has become much less personal, and consequently misunderstood" (2014, p. 106).

Modern communication technologies, which facilitate communication, are called computer-mediated communication (CMC). Researchers who look into the specificity of CMC agree that it refers to human interaction via computers as tools to exchange text, images, audio or video. Spitzberg defines CMC as "any human symbolic text-based interaction conducted or facilitated through digitally-based technologies" (2006, p. 630). According to the author

"this working definition includes the Internet; cellular phone text, instant messaging (IM), multiuser interactions (MUDs \& MOOs); email and listserv interactions; and text-supplemented videoconferencing" (e.g., decision support systems). This decision requires actual people engaged in a process of message interchange in which the medium of exchange at some point is computerized" (Spitzberg, 2006, pp. 630-631).

Some researchers call CMC as digitalk (Dino \& Gustilo, 2015). They explain that digitalk is a new way to communicate in the digital setting, which evidently shows manipulation in the spellings and conventions that occur when people communicate with each other. Crystal, a famous British linguist, compares CMC with conventional communication and suggests that the main differences that differentiate CMC from conventional communication are lack of simultaneous feedback, the absence of a non-segmental phonology, and its ability to carry on multiple interactions simultaneously (2005). Van Dijk thinks that the most significant problem regarding CMC is the absence of non-verbal cues. The author explains that these limitations make it harder to build a good relationship with the partners of conversation (van Dijk, 2006, p. 228). van Dijk also points out that already in 1990's people were talking 
that the use of CMC caused social isolation, reduced real-life involvement, and impoverished social interaction. Such thinking is still frequent today. Besides, some researchers have noted deception as one more negative feature of CMC. The majority of authors who conducted research in digital deception claim that online deception is possible because of the reduced physical cues. Researchers have identified the linguistic factors which in their opinion can be ascribed to online deceivers. They include the use of long sentences, special types of questions, first-person singular pronouns, causation terms, words related to senses, etc. (Hancock et al., 2008). Thus, CMC not only affects communication process. It also shapes the society. Majority of authors who conducted research in digital deception claimed that online deception is possible because of the reduced physical cues. The research is available which looks into linguistic factors ascribed to online deceivers. They include the use of long sentences, special types of questions, first-person singular pronouns, causation terms, words related to senses (Hancock et al., 2008).

In view of the above-mentioned, this paper looks into the features of CMC in emails and websites of insurance companies.

\section{Computer-mediated business communication}

A substantial amount of research is available on business communication in general. However, there are not many studies in the field of computer-mediated business discourse. Due to the spread of globalization, businesses are expanding to international markets and thus the need occurs for communication in a foreign language. The natural business process paved the way for the English language, and it has become lingua franca of business communication. As stated by Fanha Martins, "the English language is growing, and its dominance has been demonstrated in social and commercial communications as well as academics in the entire globe" (2017, p. 61).

From the linguistic point of few, computer-mediated business communication (CMBC) differs from conventional business communication. Jiang specifies that lexicon is the most significant aspect in business communication and provides in his opinion the most prominent lexical features of business communication (2015, p. 30). He outlines the following three groups of lexical features in business communication - specialization of vocabulary, the formalization and standardization of vocabulary, and polysemy, compound and borrowed words.

Specialization of vocabulary means the use of abbreviations. Popular business terms are often written in the form of acronyms, for example, CWO (cash with order), L/C (letter of credit), COD (cash on delivery), D/A (documents against acceptance), etc. Besides, business communication is often characterised by the use of the same word but in different meanings and in different contexts. For example, the word "move" gets a completely different meaning when used in business context where it means to "suggest".

Formalization and standardization of vocabulary means that business lexicon employs formal words which are seldom used in everyday communication. The examples provided in the literature include the verb "purchase" which is used instead of the verb "buy", the verb "commence" stands for the verb "begin", the verb "tell" is generally substituted with the verb 
"inform", etc. Other indicators of formalness identified in different studies on the language of business communication cover, for example, the replacement of verb phrases with verbs ("continue" is replaced by "keep on", "add to" is replaced by "supplement", etc.), the use of prepositional phrases ("in accordance with" replaces "according to", "for the purpose of" is used instead of "for", "if" is substituted with "in the case of", etc.). The researchers also reveal that the language of business communication is not only formal but also concise. Therefore, wordiness and excessive use of conjunctions is avoided.

Finally, polysemy in business communication means that some words get different meanings in business contexts in comparison with their conventional meanings. For example, the word "average" often picks up different meanings in business contexts. Depending on the context it may refer to "an intermediated level of price" or to "the loss of ship or cargo which is caused by damage at sea". Compound words in business environment are called neologisms. They usually are the result of new technologies and the examples provided by different authors include "online publishing, cyber-marketing, network marketing, valueadded-service", etc. It has also been noted that around 50\% of business English terminology is borrowed from other languages (Jiang, 2015).

However, it is not only the lexis that makes Business English different from General English. Grammatical features of business language are of great relevance as well. As indicated by Jiang, "articles, prepositions and objects in some sentences in commercial letters can be omitted or are customarily not used for the sake of brevity" (2015, p. 32). Fanha Martins (2017, pp. 63-64) illustrates the change in the use of grammatical by marking the following grammatical features of Business English:

- dropping the use of the definite and indefinite articles;

- omission of the third person singular present tense;

- plural for uncountable nouns;

- interchangeable use of "who" and "which";

- extended application of semantically flexible verbs;

- the regular use of invariable tag questions such as, "isn't it".

In addition, stylistic features are also of great significance in structuring and conveying the meaning in business communication. The study conducted by $\mathrm{Yu}$ and $\mathrm{Fu}$ show that successful business communication follows the so called "Three Cs" principle: clarity, conciseness and courtesy. Clarity means that there is no place for ambiguities in business communication. Business writings, for example, have to be direct and the words and sentences have to be simple. Therefore, sentences have to be short and without any unnecessary words. Conciseness indicates brevity. Concise communication increases efficiency and helps to assure clarity. Courtesy, as indicated in literature plays a significant role in business communication, especially in business correspondence. Courtesy indicates that business partners should demonstrate respect to each other. Particularly polite language is the key to successful business communication and strong business relations (Yu \& Fu, 2014, p. 369).

The analysis of research on CMBC has revealed that researchers acknowledge the existence of significant differences between $\mathrm{CMBC}$ and conventional business correspondence. They mention, for instance, that compared to $\mathrm{CMBC}$ conventional business correspondence is much more informal, colloquial and individual (Yue \& Wang, 2014, p. 50). The study conducted by Gimenez reveals that online business communication differs from conventional 
business communication in three categories: register, style, and contextual aspects. From the register perspective, business e-mails are simple and straightforward. Preference is given to demonstrative modifiers. Business e-mails tend to rely on immediate context and elliptical forms. From the stylistic perspective, business e-mails employ unconventional abbreviations, personalized abbreviations, contractions, colloquial expressions, they are characterised by the neglect of punctuation, as well as unconventional ways of addressing. From the contextual perspective, business e-mails are sent without paying attention to hours and the days of week (Gimenez, 2000, pp. 241-247). Thus, there is a clear indication that CMBC has undergone changes and deviated from the conventional norms of traditional business communication and is still under process.

Most researchers accentuate the positive characteristics of CMC. However, there are studies that list the limitations of CMC. As mentioned by Bubas, CMC produces a number of negative challenges that include limited social presence, anonymity, reduced or delayed message feedback, depersonalized communication (2006). Limited social presence is looked upon as the degree of salience of the other person in a mediated communication and the consequent salience of interpersonal interactions between mediating parties. Anonymity refers to the situation where the communicating parties can be non-identifiable and untrackable. Anonymity may trigger both a positive and a negative result, i.e. it may, for instance, lead either to deception situation or the situation where the parties are protected from social evaluation and scrutiny. Reduced/delayed message feedback attributes to slowed or sometimes lost response in the communication process. This may lead to misunderstandings between communicators and frequently to failure of resolving the matter. Depersonalized communication may remove any sense of connectedness or intimacy between communicators and cause the absence of empathy. Kushlev and Heintzelman do not fully agree with this attitude towards limitations of CMC and maintain that communicators compensate the limitations of CMC by their personal, social and cultural identity that they bring into the communication (2018, p. 702). A provocative viewpoint in this respect is getting use of "covert" aspect of CMC. The communicators get more relaxed and spontaneous that can often trigger curiosity which in turn can activate creative thinking. With regard to Adair, true curiosity is usually followed by the process of thinking and answering questions and is the appetite of creative thinking (2009, p. 34).

Culture is also looked upon as another significant business communication pillar. Researchers agree that cultures are created through communication and that communication is the means of human interaction through which cultural characteristics are created and shared. Indeed, culture and communication are closely interconnected. According to WenCheng, Chien-Hung and Ying-Chien communication is the foundation of human contact. Communication helps to share ideas, exchange experiences and modify values. Communication is a tool to make and preserve culture. "Cultures are created through communication; that is, communication is the means of human interaction through which cultural characteristics are created and shared" (Wen-Cheng et al., 2011, p. 112).

In the global world of today business communication is global. It means that business partners often come from different cultural backgrounds and the absence of international competencies may pose problems in business communication across cultures. Different 
cultures may have different rules and norms and favour different means of business communication.

It is worth noting that there is a study which classifies six cultural dimensions that may facilitate cross-cultural business communication. With reference to Geert Hofstede quoted in "Intercultural Business Communication - A Comparison of China and Sweden" (Guo, 2017, pp. 10-12), the following cultural dimensions are identified:

- Power distance index which expresses "the extent to which the less powerful members of institutions and organizations within a country expect and accept that power is distributed unequally";

- Individualism versus collectivism which expresses "the degree of interdependence a society maintains among its members";

- Masculinity versus femininity which expresses "the extent of which society tends to lean with regards to stereotypical gender roles and values";

- Uncertainty avoidance index which expresses "the extent to which the members of a culture feel threatened by ambiguous or unknow situations and have created beliefs and institutions that try to avoid these";

- Long term orientation versus short term normative orientation which explains "how every society has to maintain some links with its own past while dealing with the challenges of the present and future";

- Indulgence versus restraint which expresses "the extent to which people try to control their desires and impulses".

Adamczyk claims that culture and international business communication are closely interrelated and cultural issues influence

"numerous aspects of the international business communication: business relations, negotiations, international management, marketing communication strategies, decisions concerned with the brand or consumer behaviours" (2017, p. 152).

The author further suggests that there are three types of cultures regarding business environment: transaction-orientated cultures, moderately transaction-orientated cultures, and relationship-orientated cultures.

\section{Computer-mediated business communication in e-mails}

As mentioned above, business communication is under regular development due to the constant change of modern communication technologies. CMC has become a complex phenomenon of business reality: business communication online has evolved over time and finally been recognized as a new register, of which the tenor, mode, field are of distinct features in contrast with traditional business communication (Wang, 2012).

Most of the researchers maintain, that the most popular type of CMBC is e-mail. With reference to linguistic aspects (grammar, lexis, style, etc.) in e-mails, researchers claim that the language of computer-mediated business correspondence is more straightforward and distinctive than in traditional letters. They came to this conclusion after they had analysed the use of various types of hedges in business e-mails. The research employed the classification of hedges in business e-mails provided in the research "Hedges Used in Business Emails: A Corpus Study on the Language Strategy of International Business Communication Online" 
(Yue \& Wang, 2014, p. 51). The results of the research revealed that more than a half of various types of business e-mails use hedges. With reference to the mentioned study "hedges are prominently used in various business emails, with marketing emails ranking the first, inquiry emails the second, quotation emails and follow-up emails the last" (Yue \& Wang, 2014, p. 51).

Regretfully, there are not many studies on CMBC and especially on business e-mails. Worth mentioning is the study completed by Gimenez who analysed the corpus of business e-mails of a particular company and identified the linguistic features of business e-mails (2000, pp. 241-247). This research has been briefly mentioned above, however, with reference to available research that looks into linguistic features of e-mails it can be considered as one of the most thorough. The author accentuates three linguistic categories: register, style, and contextual aspects. Here are the examples provided in this study:

- Register: The author notes that 1) business e-mails stand out from conventional business letters for their simple, straightforward syntactic structures and in his opinion this is the sign of the preference for co-ordinated rather than subordinated ideas (e.g. "Please send me CIF [...] (place) prices for [...] (band + model)"; "Also, your other stocks with details"); 2) Demonstrative modifiers are preferred to definite articles (e.g. "What I need you to do is to inform your agent in [...] (place) about the L/C shift?"); 3) There is a reliance on immediate context, which is marked by unstated proposition relationships (e.g. "Pls. don't include the shipping costs. I can arrange that with my agent"); 4) Elliptical forms that echo unplanned spoken language (e.g. "If interested, notify us accordingly");

- Style: According to the author, style is expressed by 1) The use of unconventional abbreviations which suggests that the language of business e-mails is rather informal and personalized (e.g. a sender puts only his/her first name initials which are followed by his/her last name or only first name alone); 2) The use of personalized abbreviations (e.g. "tks" (thanks); "plse" (please)); 3) Contractions (e.g. "We're looking for prices"); 4) Colloquial expressions (e.g. "Frankly speaking"; "Just drop me an e-mail"); 5) The neglect of punctuation, capitalization, and spelling (e.g. "I would like to confirm"; "If you have any questions please contact our Customer Service department"); 6) Unconventional ways of addressing, for instance, no greeting at all or, such phrases as "Hello from [...]" (name of company); "Dear Mr [...] (last name)";

- Contextual aspects: These aspects of business e-mails refer to the fact that nowadays people do not pay attention when (on which day of the week or hour of the day) they compose and send e-mails. The study of Gimenez reveals that nowadays e-mails are sent even on Sundays which means that there is a lack of privacy (2000, pp. 241-247).

\section{Computer-mediated business communication in the websites in insurance companies}

CMC features can vary in different varieties of their use. The analysis of some insurance companies' websites has shown that linguistic characteristics there do not always coincide with the ones that are identified in e-mails. For example, there is a tendency to omit prepositions, articles, and objects in e-mails. However, the collected data has revealed that these language patterns are usually not omitted in business websites (e.g. "You invest a lot of time and money to get your home just right and it contains some of your most prized possessions, so it makes 
sense to protect your investment with the right home insurance" (Swinton Insurance (SI)); "Talk it through with an expert. For new single majority, life insurance can be a good partner" (New York Life Insurance Company (NYLIC)). The provided examples illustrate that insurance companies do not omit articles and prepositions in their websites. However, some companies tend to omit objects. For instance, "Here's to peace of mind" (China Taiping Insurance Holdings $(\mathrm{CHTIH})$ ); "Zero deductible, zero rate hikes, zero worries" (Lemonade Insurance Company $(L I C))$; "It's easy - call or click to get started!" (Mattison Insurance Agency, Inc. (MIAI))).

Another difference from e-mails is that in websites the present tense is used instead of the past tense for things which have just passed away. Some researchers point out that this grammatical feature helps to make the statement as vivid as talking face-to-face (Jiang, 2015, p. 34). Alongside with the use of present tenses preference is put on active voice (e.g. "If you're starting a family, buying a home, planning a trip, or protecting your portfolio of properties, our coverage and products can help give you a stronger future" (American International Group $(A I G)$ ); "If your car is vandalised and you have a crime reference number, you won't lose your No Claim Discount when you make a claim” (Churchill Insurance $(C H I))$ ).

As mentioned above, a typical feature of CMC is formalization and standardization of the vocabulary items used. The vocabulary of $\mathrm{CMBC}$ has to be not only formal but also concise. Available research suggests that brevity is the characteristic of business English. Thus, excessive wordiness and (possibly) long sentences in CMBC should be avoided. The collected examples exhibit that in e-mails the characteristic of conciseness and short wordiness is followed. However, the analysis of websites of considered insurance companies demonstrates that $\mathrm{CMBC}$ patterns employ long sentences with numerous subordinate clauses (e.g. "This insurance indemnifies you against your legal liability in respect of accidental bodily injury to third parties and/or accidental loss and/or damage to property belonging to third party arising in connection with your business anywhere in Singapore or specific place of business" (CHTIH); "As a small business it is vital to ensure that you can focus on growing your business so you don't want to" have any nagging doubts about your insurance cover as you work with new customers and "come into contact with members of the public who could claim against you if the unthinkable happens" $(S I)$ ). There were only a few cases of short simple sentence pattern use (e.g. "Find out how little costs to protect them. Not any more. No more waiting for long overdue replies" (Singapore Life (SL)); "In Churchill we believe in being there for you"; "We'll cover up to $£ 10$ million of medical expenses" $(C H I)$ ).

The collected examples have revealed a few more linguistic aspects related to the language of websites. They are the following:

- First: rhetorical questions. The analysis of the websites of considered insurance companies has revealed that there is an abundant amount of rhetorical questions which, as known, are used to intensify persuasion on readers. They are asked though an answer is not expected because it is already known. Rhetorical question is a strong stylistic devise that helps to capture a reader's attention and may subtly influence his/her choice (e.g. "Want reassurance from your insurance? What if one hits you?" (SI); "Is it required for all self-employed electricians?" (CHI); “Too much coverage? Insurance needs change. Have yours?" (NYLIC); "Ready to get started on your business quotes? How much home-owner's insurance do I need?" (MIAI); "Between 50 and 85 years old? Trying to determine if you need life insurance?" (AIG); "Why life insurance, 
Familiar with life insurance?” $(S L))$. Researchers identify rhetorical, stylistic, persuasive functions of the choice of rhetorical questions in communication in general (Abioye, 2009). Nonetheless, these functions perfectly well reflect the functions of the use of rhetorical questions in CMBC. As seen from the provided website examples rhetorical questions may draw attention, charge emotions, stimulate decision-making, embellish the format, etc.;

- Second: exclamatory sentences. The collected data has shown that exclamatory sentences, as a stylistic devise are also frequent in the websites of considered insurance companies. They likewise enhance emotions and strengthen feelings (e.g. "A quick and easy way for your users to protect their homes and stuff!" (LIC); "We do not work for an insurance company; we work for you!" (MIAI); "We will even tell you how to apply!" (AIG); "That's why we want to reward you for your efforts!" $(S L)$; "Increase your capital liquidity and ease your financial burden!” (CHTIH));

- Third: capitalization. This stylistic devise is used to spark emotional reaction from a reader. Yet it is not as frequently used as rhetorical questions and exclamatory sentences (e.g. "MUST, MUST NOT" (CHI); "Get a FREE, no obligation quote today!", "As your insurance agents, it is our responsibility to provide YOU the best service and the best coverage, at the best possible price" (MIAI); "We provide progressive insurance IDEAS and innovative SOLUTIONS that are built on TRUST" (CHTIH)).

$\mathrm{CMBC}$ in websites of considered insurance companies, thus, is semi-formal, i.e. it uses both formalized and informal language features. There is no clear indication that formalized features outweigh informal or vice versa. Some websites tend to be more informal and therefore employ more non formalized language features, while other websites do the opposite. The informal approach establishes the field for exploiting creativity in selecting the language features that foster good working relationship.

\section{Conclusions}

The analysis of the research on CMBC and the collected examples from the websites of some insurance companies have led to the following conclusions:

- CMBC differs from conventional business communication and the lexicon is the most significant side of their difference. Creative approach in using the right lexis facilitates the effectiveness of digital business communication, reinforces clarity, conciseness and courtesy;

- CMBC undoubtedly facilitates business communication. Communication in business is listed to be foundational. Creativity aspect adds to the achievement of business goals and fosters good working relationship. However, the limitations of CMBC (limited social presence, anonymity, reduced / delayed message feedback, depersonalised communication, deception) may have negative impact on society;

- From the linguistic point of view, CMBC has turned from the conventional business communication, yet this turn can be described as partial. Like conventional business communication, $\mathrm{CMBC}$ follows formalization and standardization requirements in the area of lexis, but at the same time there is a tendency to use less formal language indicators which, as is believed, can easier reach a reader;

- Linguistic characteristics of CMBC in e-mails and websites of insurance companies do not always coincide. While e-mails tend to use really formal linguistic elements, the websites show the move towards creative expression of informal means. 


\section{References}

Abioye, T. O. (2009). Typology of rhetorical questions as a stylistic device in writing. The International Journal of Language Society and Culture, 29. https://core.ac.uk/download/pdf/12356658.pdf

Adair, J. (2009). The art of creative thinking: how to be innovative and develop great ideas. Series: The John Adair Leadership Library. Cogan Page.

Adamczyk, M. (2017). The importance of cultural differences in international business. Central European Review of Economics and Management, 1(2), 151-170. https://doi.org/10.29015/cerem.335

Bubas, G. (2006, 19-23 June). Competence in computer-mediated communication: an evaluation and potential uses of a self-assessment measure. Proceedings of 56th Annual Conference of the International Communication Association. 56th Annual Conference of the International Communication Association. Dresden, Germany. https://www.researchgate.net/publication/306056294_Competence_in_Computer-Mediated_Communication_An_Evaluation_and_Potential_Uses_of_a_SelfAssessment_Measure

Cherry, B. (2019). Characteristics of creativity in business. TruScribe. https://truscribe.com/characteristics-of-creativity-in-business/

Conrad, D. (2014). Workplace communication problems: inquiries by employees and applicable solutions. Journal of Business Studies Quarterly, 5(4), 105-116.

Crystal, D. (2005, February). The scope of internet linguistics. Paper Given Online to the American Association for the Advancement of Science Meeting. http://www.google.lt/url?sa=t\&r $\mathrm{ct}=\mathrm{j} \& \mathrm{q}=\& \mathrm{esrc}=\mathrm{s} \&$ source $=\mathrm{web} \& \mathrm{~cd}=3 \& \mathrm{ved}=2 \mathrm{ahUKEwiO} 44 \mathrm{SM} 0 \mathrm{obp}$ AhUOyaQKHeZVC IMQFjACegQIARAB\&url=http\%3A\%2F\%2Fwww.davidcrystal.com\%2F\%3Ffileid\%3D4113\&usg=AOvVaw2rMpQyZDOYUxeteIXpk3Na

Dijk, van J. (2006). The network society. Social aspects of new media. SAGE Publications.

Dino, Ch. M., \& Gustilo, L. E. (2015). Digitalk: an exploration of the linguistic features of CMC. International Journal of Languages, Literature and Linguistics, 1(1), 51-55. https://doi.org/10.7763/IJLLL.2015.V1.11

Fanha Martins, H. (2017). Perspectives on business English as Lingua Franca in business communication. Teacher Education and Curriculum Studies, 2(5), 61-67. https://doi.org/10.11648/j.tecs.20170205.11

Gimenez, J. C. (2000). Business e-mail communication: some emerging tendencies in register. English for Specific Purposes, 19(3), 237-251. https://doi.org/10.1016/S0889-4906(98)00030-1

Guo, Y. (2017). Intercultural business communication - a comparison of China and Sweden (Master of Arts Thesis). University of Groningen/Uppsala University. Groningen, Netherlands/Uppsala, Sweden. https://www.diva-portal.org/smash/get/diva2:1139216/FULLTEXT01.pdf

Hancock, J. T., Curry, L. E., Goorha, S., \& Woodworth, M. (2008). On lying and being lied to: a linguistic analysis of deception in computer-mediated communication. Discourse Processes, 45(1), 1-23. https://doi.org/10.1080/01638530701739181

Jiang, Y. (2015). Study of language features of business English. Higher Education of Social Science, $8(5), 29-35$.

Kushlev, K., \& Heintzelman, S. J. (2018). Put the phone down: testing a complement-interfere model of computer-mediated communication in the context of face-to-face interactions. Social Psychological and Personality Science, 9(6), 702-710. https://doi.org/10.1177/1948550617722199

Pearson, J. C., \& Nelson, P. E. (2000). An introduction to human communication: understanding and sharing. McGraw Hill Education.

McLuhan, E. (2008). Marshall McLuhan's theory of communication: The Yegg. Global Media Journal Canadian Edition, 1(1), 25-43. 
Rosengren, K. E. (2006). Communication: an introduction. SAGE Publications Ltd.

Spitzberg, B. H. (2006). Preliminary development of a model and measure of Computer-Mediated Communication (CMC) competence. Journal of Computer-Mediated Communication, 11(2), 629666. https://doi.org/10.1111/j.1083-6101.2006.00030.x

Tharp, T., \& Reiter, M. (2009). The creative habit: learn it and use it for life. A Practical Guide. Simon \& Shuster Paperbacks.

Wang, S. L. (2012). The change of studies of intercultural business communication in cyberspace. Academic Exchange, 2, 134-137.

Wen-Cheng, W., Chien-Hung, L., \& Ying-Chien, Ch. (2011). Cultural diversity and information and communication impacts on language learning. International Education Studies, 4(2), 111-115.

Yu, Z., \& Fu, Y. (2014, 5-7 May). A study on the characteristics and writing principles of business correspondence. Proceedings of the International Conference on Education, Language, Art and Intercultural Communication (ICELAIC 2014). 2014 International Conference on Education, Language, Art and Intercultural Communication (ICELAIC 2014) (pp. 369-372). Zhengzhou, Henan, China.

Yue, S., \& Wang, X. (2014). Hedges used in business emails: a corpus study on the language strategy of international business communication online. Higher Education Studies, 4(6), 49-57.

https://doi.org/10.5539/hes.v4n6p49

\title{
SKAITMENINĖS VERSLO KOMUNIKACIJOS LINGVISTINIAI ASPEKTAI KAIP KÜRYBIŠKUMO RAIŠKA
}

\author{
Irena DARGINAVIČIENĖ, Jelena SUCHANOVA
}

\begin{abstract}
Santrauka
Skaitmeninè verslo komunikacija yra nuolatinio šiuolaikinių technologijų vystymosi ir jų pokyčių rezultatas. Mokslininkai teigia, kad skaitmeninès technologijos turi ir teigiamą, ir neigiamą poveikị verslo komunikacijai. Kūrybiškumas verslo komunikacijoje tampa esminiu postūmiu igyvendinant verslo galimybes. Su kūrybiškumu susijusi veikla verslo komunikacijoje - tai ne tik vaizduotès išraiška ar originalių idejų pateikimas. Tai ir inovacijos, ir novatoriškumas, ir inovatyvių skaitmeninių technologijų naudojimas. Visa tai skatina naujų idejų atsiradimą, stiprina kritinị mąstymą, atveria naujus kelius verslo ambicijoms. Tyrimo tikslas - skaitmeninès verslo komunikacijos kalbinių charakteristikų analizè. Nagrinèjami dviejų tipų skaitmeninio verslo diskursai: elektroninio pašto ir draudimo bendrovių internetinių svetainių kalba. Kalbos vartojimo požiūriu, skaitmeninè verslo komunikacija skiriasi nuo įprastos verslo komunikacijos. Leksikos, pavyzdžiui, specialiosios leksikos ir standartizuotų pasakymų, vartojimas yra būtinas, kad ši komunikacija būtų sèkminga. Svarbios yra ir gramatinès skaitmeninès verslo komunikacijos ypatybès. Be to, skaitmeninejje verslo komunikacijoje naudojamos stilistikos priemonès padeda pabrèžti perduodamą mintị, tgalina siekti aiškumo ir išraiškos gaivumo. Analizuotų skaitmeninès komunikacijos pavyzdžių lingvistiniai elementai ne visada sutampa. Tyrimas atskleidè, kad draudimo bendrovių svetainių verslo kalba, lyginant su elektroninių laiškų verslo kalba, yra mažiau formali, joje daugiau kūrybiškumo ir laisvumo raiškos.
\end{abstract}

Reikšminiai žodžiai: verslo diskursas, skaitmeninė komunikacija, kūrybiškumas, elektroninis laiškas, lingvistiniai elementai, draudimo bendrovių svetainès. 